\title{
FORMULASI DAN UJI AKTIVITAS ANTIBAKTERI PATCH BUKAL MUKOADHESIF ESTRAK CENGKEH (Syzygium aromaticum L.) DENGAN KOMBINASI POLIMER POLIVINIL PIROLIDON (PVP) DAN NATRIUM KARBOKSIMETIL SELULOSA (NA-CMC) TERHADAP BAKTERI Streptococcus mutans
}

\author{
Vina Purnamasari M, Iskandar Zulkarnain \\ Fakultas Farmasi Universitas Muslim Indonesia \\ Email : vina.purnamasari@umi.ac.id
}

\begin{abstract}
Clove extract (Syzygium aromaticum) contains eugenol 70\% - 85\%. The clove extract is formulated in the form of mucoadhesive buccal patches. The purpose of this study was to obtain the formulation for mucoadhesive buccal patches having optimal stability that has good pharmaceutic properties and also effectively inhibits the Streptococcus mutans bacteria. The research design used was laboratory experimental research. The mucoadhesive buccal patches with a combination of PVP and HPMC polymers made in 5 formulas based on their concentration, formula $11 \% \mathrm{Na}-\mathrm{CMC}$ concentration, formula 2 2\% Na-CMC concentration, formula $32 \%$ PVP concentration, formula $43 \%$ PVP concentration, formula 5 combination of $\mathrm{Na}$ CMC and PVP with concentrations of $1 \%$ and $2 \%$. Patches obtained were tested for physical properties including organoleptic examination, surface tension, weight uniformity, thickness uniformity, folding endurance and $\mathrm{pH}$ patch surface. The patch is also tested for its antimicrobial power by measuring the zone of bacterial resistance. The results showed that the buccal patches of clove extract produced a dark brown color with opaque transparency, smooth surface texture with a patch weight of around $66.67 \mathrm{mg}-140.67 \mathrm{mg}$, standard deviation of patch thickness around $\pm 0.009- \pm 0.058$, folding endurance more than 300 times, surface $\mathrm{pH}$ ranged from $6.40-6.60$, and antimicrobial activity shows that all patch formulations can inhibit the growth of Streptococcus mutans bacteria to prevent dental caries, but the formula that has the largest inhibition zone was formula IV with a inhibition zone of about $1.667 \mathrm{~cm}$.
\end{abstract}

Key Words : Clove extract, mucoadhesive buccal patches, PVP, Na-CMC.

PENDAHULUAN

Cengkeh

(Syzygium

aromaticum atau Eugenia

Aromatucum), dalam bahasa inggris

disebut cloves, adalah tangkai bunga

kering beraroma dari keluarga pohon
Myrtacace. Cengkeh (Syzygium aromaticum) mengandung eugenol $70 \%$ - $85 \%$, asetil eugenol, alpha, betha-kariofilen, furfural, eugenin, eugenitin, isoeugenitol, tannin dan asam oleanolat. Efek farmakologis dari 
Formulasi dan uji aktivitas antibakteri Patch bukal mukoadhesif estrak cengkeh dengan kombinasi Polimer Polivinil Pirolidon dan Natrium Karboksimetil Selulosa terhadap bakteri Streptococcus mutans

cengkeh dapat meredakan nyeri, cengkeh dapat diformulasi dalam sebagai stimulan, menghangatkan tubuh, antiseptik, antispasmodik, karminatif, anastetik lokal, menghilangkan kolik dan antibatuk. ${ }^{1}$ Selain itu minyak cengkeh merupakan sumber agen antimikrobial melawan bakteri dalam mulut yang biasanya dihubungkan dengan penyakit karies gigi dan periodontal sehingga dapat dipakai sebagai bahan aktif atau bahan pembuatan obat kumur. ${ }^{2}$

Hasil penelitian menujukkan bahwa formula obat kumur yang dihasilkan dari minyak cengkeh dapat menghambat tumbuhnya bakteri Streptococcus mutans dan Streptococcus viridians yang dapat menyebabkan terjadinya plak gigi. ${ }^{2}$ Menurut penelitian yang telah dilakukan oleh Suwondo syarif pada tahun 20073 , konsentrasi pada cengkeh (Syzygium aromaticum) 1\% mampu menghambat bakteri Streptococcus mutans sebesar $67,33 \%$.

Daerah bukal pada rongga mulut merupakan target yang menarik untuk pemberian obat. Penghantaran bukal melibatkan pemberian obat-obat yang diinginkan melalui membran mukosa bukal yang berada pada rongga mulut. ${ }^{4}$ Dengan demikian sediaan patch bukal. Salah satu komponen paling penting dalam sediaan Patch adalah polimer. Beberapa kelompok polimer hidrofilik seperti natrium karboksimetil sellulosa (Na-CMC) dan polivinil pirolidon (PVP) telah digunakan dalam penghantaran mukoadesif. ${ }^{5}$ Na-CMC digunakan sebagai matriks karena memiliki kekuatan mukoadhesif yang tinggi dan Na-CMC biasa digunakan untuk melindungi perlekatan produk dengan jaringan tubuh dari kerusakan. PVP dapat meningkatkan pelepasan obat karena pembentukan pori dan mencegah kristalisasi obat dalam matriks. ${ }^{6}$

\section{METODE PENELITIAN}

\section{Alat dan Bahan}

Alat yang digunakan adalah erlenmeyer $1000 \mathrm{~mL}\left(\right.$ pyrex $\left.^{\circledR}\right)$, gelas kimia $5 \mathrm{~mL}\left(\right.$ pyrex $\left.^{\circledR}\right)$, gelas ukur $10 \mathrm{~mL}$ dan $25 \mathrm{~mL} \quad\left(\right.$ pyrex $\left.^{\circledR}\right), \quad \mathrm{pH}$ meter (Eutech $^{\circledR}$ ), labu ukur $5 \mathrm{~mL}$ dan $100 \mathrm{~mL}$ (pyrex $^{\circledR}$ ), oven (memmert ${ }^{\circledR}$ ), stirer (IKA SARTORIUS ${ }^{\circledR}$ ), Timbangan analitik (Ohaus) dan waterbath shaker (Memmert $\left.^{\circledR}\right)$, desikator. Bahan yang digunakan berupa ekstrak cengkeh, eugenol baku (Sigma Aldrich), Polivinilpirolidon, Na-CMC, Propilenglikol, etanol 96\%, pilisorbat 
Formulasi dan uji aktivitas antibakteri Patch bukal mukoadhesif estrak cengkeh dengan kombinasi Polimer Polivinil Pirolidon dan Natrium Karboksimetil Selulosa terhadap bakteri Streptococcus mutans

80, Aquadest, Natrium dihidrogen fosfat, dinatrium hidrogen fosfat, kertas saring dan aluminium foil.

\section{Prosedur Kerja}

\section{Pembuatan Formula}

Pembuatan formula patch bukal ekstrak cengkeh dengan polimer $\mathrm{Na}-\mathrm{CMC}^{7}$

Dibuat dispersi Na-CMC dengan cara Na-CMC $(1 \%$ b/v $)$ dimasukkan kedalam $10 \mathrm{~mL}$ aquades lalu dipanaskan hingga melarut dan diaduk hingga membentuk dispersi yang transparan. Ekstrak cengkeh dimasukkan kedalam dispersi $\mathrm{Na}-\mathrm{CMC}$ dan diaduk hingga homogen kemudian ditambahkan propilenglikol $0,2 \%$ dan polisorbat 80 0,2\% kemudian diaduk hingga homogen. Dispersi ekstrak cengkeh diaduk kembali hingga homogen dan dituang diatas cawan petri kemudian dikeringkan di dalam oven pada suhu $50^{\circ} \mathrm{C}$ selama 24 jam, setelah patch mengering selanjutnya dipotong sebesar $2 \times 2 \mathrm{~cm}$. Hal yang sama dilakukan dengan konsentrasi $\mathrm{Na}-\mathrm{CMC} 2 \%$.

\section{Pembuatan formula patch bukal ekstrak cengkeh dengan polimer PVP $^{7}$}

Dibuat dispersi polivinilpirrolidon (PVP) dengan cara PVP (2\%b/v) dimasukkan kedalam $10 \mathrm{~mL}$ aquades

dan dipanaskan hingga melarut dan diaduk hingga membentuk dispersi yang transparan. Ekstrak cengkeh dimasukkan kedalam dispersi PVP dan diaduk hingga homogen kemudian ditambahkan propilenglikol dan tween 80 0,2\%. Dispersi ekstrak cengkeh diaduk kembali hingga homogen dan dituang diatas cawan petri kemudian dikeringkan di dalam oven pada suhu $50^{\circ} \mathrm{C}$ selama 24 jam, setelah patch mengering selanjutnya dipotong sebesar $2 \times 2 \mathrm{~cm}$. Hal yang sama dilakukan untuk PVP dengan konsentrasi $3 \%$.

\section{Pembuatan formula patch bukal} ekstrak cengkeh dengan kombinasi polimer $^{7}$

Masing-masing polimer NaCMC $(1 \%$ b/v) dan PVP (2\% b/v) dilarutkan dalam $10 \mathrm{ml}$ aquades dan dipanaskan hingga melarut dan diaduk hingga membentuk dispersi yang transparan. Ekstrak Cengkeh dimasukkan ke dalam campuran dispersi Na-CMC dan PVP kemudian diaduk hingga homogen. Kedalam dispersi ditambahkan propilenglikol $0,2 \%$ dan polisorbat $80 \quad 0,2 \%$ selanjutnya diaduk hingga homogen. Dispersi ekstrak cengkeh kemudian dituang di atas cawan petri dan dikeringkan pada suhu $50^{\circ} \mathrm{C}$ selama 
Formulasi dan uji aktivitas antibakteri Patch bukal mukoadhesif estrak cengkeh dengan kombinasi Polimer Polivinil Pirolidon dan Natrium Karboksimetil Selulosa terhadap bakteri Streptococcus mutans

24 jam, setelah patch mengering selanjutnya dipotong sebesar 2x2 cm.

\section{Evaluasi patch Bukal Ekstrak Cengkeh}

\section{Pengujian Organoleptik ${ }^{8}$}

Patch bukal minyak cengkeh diamati secara visual penampakannya berupa warna dan transparansinya.

\section{PengujianTekstur Permukaan ${ }^{7}$}

Tekstur permukaan patch bukal minyak cengkeh dievaluasi dengan menekan patch dengan jari.

\section{Keseragaman berat ${ }^{7}$}

Tiga patch dari masing-masing formula diambil dan ditimbang secara terpisah dan berat rata-rata patch dihitung dan ditetapkan standar deviasinya.

\section{Keseragaman ketebalan ${ }^{7}$}

Empat patch dari masingmasing formula diambil dan ketebalan patch diukur dengan menggunakan screw gauge pada tempat yang berbeda.

\section{Folding endurance ${ }^{9}$}

Tiga patch dari masing-masing formula dengan ukuran 2x2 cm dipotong dengan menggunakan pisau yang tajam. Folding endurance ditentukan dengan melipat secara berulang potongan kecil patch pada tempat yang sama sampai patch tersebut patah. Jumlah waktu patch

dapat dilihat pada tempat yang sama tanpa mengalamai patah merupakan nilai folding endurance.

\section{pH permukaan Patch ${ }^{7}$}

Tiga patch dari masing-masing formula dibiarkan mengembang selama dua jam pada permukaan plat agar yang mengandung $2 \% \mathrm{~b} / \mathrm{v}$ didalam larutan dapar fosfat hangat $\mathrm{pH}$ 6,6. $\mathrm{pH}$ permukaan diukur dengan menggunakan $\mathrm{pH}$ meter yang ditempatkan pada permukaan patch yang mengembang.

\section{Evaluasi Mikrobiologi ${ }^{10}$}

Medium NA steril dimasukkan kedalam vial steril sebanyak $10 \mathrm{~mL}$, lalu ditambahan suspensi mikroba uji sebanyak 0,0202 mL kemudian dihomogenkan.

Setelah dihomogenkan, dimasukkan masingmasing $10 \mathrm{~mL}$ kedalam lima cawan petri steril. Lalu disiapkan 15 buah paper disk yang akan dilekatkan pada patch. Semua paper disk dicelupkan selama kurang lebih 1 jam. Kemudian paper disk yang telah dilekatkan pada patch tadi ditanamkan pada kedua cawan petri yang berisi medium NA yang telah bercampur dengan biakan Streptococcus mutans. Kemudian kelima cawan petri tersebut diinkubasi selama 1 × 24 jam pada suhu $37^{\circ} \mathrm{C}$, 
Formulasi dan uji aktivitas antibakteri Patch bukal mukoadhesif estrak cengkeh dengan kombinasi Polimer Polivinil Pirolidon dan Natrium Karboksimetil Selulosa terhadap bakteri Streptococcus mutans

lalu di ukur zona hambatan pertumbuhan bakteri.

yang ditujukan untuk pemberian obat

\section{HASIL PENELITIAN}

Pada penelitian ini dibuat sediaan Patch dari ekstrak cengkeh melalui rute bukal dengan menggunakan polimer $\mathrm{Na}-\mathrm{CMC}$ dan PVP kemudian dilakukan beberapa pengujian yaitu :

\section{Pemeriksaan Organoleptik}

Tabel 1. Hasil Pemeriksaan Organoleptik Patch Bukal Ekstrak Cengkeh

\begin{tabular}{ccc}
\hline Formula & Warna & Transparansi \\
\hline I & Coklat Tua & Opaq \\
II & Coklat Tua & Opaq \\
III & Coklat Tua & Opaq \\
IV & Coklat Tua & Opaq \\
V & Coklat Tua & Opaq \\
\hline
\end{tabular}

Keterangan :

Formula I

Formula II

: Formula dengan konsentrasi Na-CMC $1 \%$

: Formula dengan konsentrasi Na-CMC $2 \%$

Formula III : : Formula dengan konsentrasi PVP 2\%

Formula IV : Formula dengan konsentrasi PVP 3\%

Formula $\mathrm{V} \quad$ : Formula dengan konsentrasi Na-CMC 1\% dan PVP $2 \%$

\section{Pengamatan Tekstur Permukaan}

Tabel 2. Hasil pemeriksaan tekstur permukaan patch bukal ekstrak cengkeh

\begin{tabular}{cc}
\hline Formula & Tekstur Permukaan \\
\hline I & Halus \\
II & Halus \\
III & Halus \\
IV & Halus \\
V & Halus \\
\hline
\end{tabular}

\section{Pengujian Keseragaman Berat}

Tabel 3. Hasil pengukuran berat patch bukal ekstrak cengkeh

\begin{tabular}{|c|c|c|c|c|c|}
\hline \multirow{3}{*}{ Formula } & \multicolumn{3}{|c|}{ Berat Patch $(\mathrm{mq})$} & \multirow{3}{*}{ Rata-Rata } & \multirow{3}{*}{ SD } \\
\hline & \multicolumn{3}{|c|}{ Replikasi } & & \\
\hline & 1 & 2 & 3 & & \\
\hline $\mathrm{I}$ & 60 & 70 & 70 & 66,67 & $\pm 5,773$ \\
\hline II & 120 & 170 & 120 & 136,67 & $\pm 28,867$ \\
\hline III & 135 & 132 & 128 & 131,67 & $\pm 3,511$ \\
\hline IV & 140 & 140 & 142 & 140,67 & $\pm 1,154$ \\
\hline $\mathrm{V}$ & 130 & 110 & 130 & 123,33 & $\pm 11,547$ \\
\hline
\end{tabular}


Formulasi dan uji aktivitas antibakteri Patch bukal mukoadhesif estrak cengkeh dengan kombinasi Polimer Polivinil Pirolidon dan Natrium Karboksimetil Selulosa terhadap bakteri Streptococcus mutans

\section{Pengujiaan Keseragaman Ketebalan}

Tabel 4. Hasil pengukuran rata-rata ketebalan patch bucal ekstrak cengkeh pada empat sisi yang berbeda

\begin{tabular}{|c|c|c|c|c|c|}
\hline \multirow{2}{*}{ Formula } & \multicolumn{4}{|c|}{ Rata-rata replikasi } & \multirow{2}{*}{ SD } \\
\hline & I & II & III & IV & \\
\hline $\mathrm{I}$ & 0,17 & 0,21 & 0,12 & 0,10 & $\pm 0,058$ \\
\hline II & 0,30 & 0,29 & 0,28 & 0,30 & $\pm 0,009$ \\
\hline III & 0,20 & 0,23 & 0,19 & 0,22 & $\pm 0,018$ \\
\hline IV & 0,20 & 0,22 & 0,20 & 0,21 & $\pm 0,009$ \\
\hline $\mathrm{V}$ & 0,30 & 0,30 & 0,28 & 0,31 & $\pm 0,012$ \\
\hline
\end{tabular}

Folding Endurance

Tabel 5. Hasil pengukuran folding endurance patch bukal ekstrak cengkeh

\begin{tabular}{ccccc}
\hline \multirow{2}{*}{ Formula } & \multicolumn{3}{c}{ Patch (Replikasi) } & \multirow{2}{*}{ Rata-rata } \\
\cline { 2 - 4 } & $\mathbf{1}$ & $\mathbf{2}$ & $\mathbf{3}$ & \\
\hline I & $>300$ & $>300$ & $>300$ & $>300$ \\
II & $>300$ & $>300$ & $>300$ & $>300$ \\
III & $>300$ & $>300$ & $>300$ & $>300$ \\
IV & $>300$ & $>300$ & $>300$ & $>300$ \\
V & $>300$ & $>300$ & $>300$ & $>300$ \\
\hline
\end{tabular}

\section{Pengujian pH Permukaan}

Tabel 6. Hasil pengukuran $\mathrm{pH}$ permukaan patch bukal ekstrak cengkeh dalam dapar fosfat $\mathrm{pH}$ 6,6

\begin{tabular}{ccccc}
\hline \multirow{2}{*}{ Formula } & \multicolumn{3}{c}{$\mathbf{p H}$ permukaan Patch (Replikasi) } & \multirow{2}{*}{ Rata-rata } \\
\cline { 2 - 4 } & 1 & 2 & 3 & \\
\hline I & 6,6 & 6,5 & 6,6 & 6,53 \\
II & 6,7 & 6,5 & 6,5 & 6,56 \\
III & 6,6 & 6,5 & 6,6 & 6,56 \\
IV & 6,5 & 6,6 & 6,7 & 6,60 \\
V & 6,4 & 6,3 & 6,5 & 6,40 \\
\hline
\end{tabular}

\section{Pengujian Aktivitas Antimikroba}

Tabel 7. Hasil pengujian aktivitas antimikroba Patch bukal ekstrak cengkeh

\begin{tabular}{ccccc}
\hline \multirow{2}{*}{ Formula } & \multicolumn{3}{c}{ Zona Hambat (cm) } & \multirow{2}{*}{ Rata-rata } \\
\cline { 2 - 4 } & Vertikal & Horizontal & Diagonal & \\
\hline I & 1 & 1 & 1,5 & 1,167 \\
II & 0,2 & 0,3 & 0,4 & 0,3 \\
III & 1,5 & 0,6 & 2,5 & 1,53 \\
IV & 1,5 & 1 & 2,5 & 1,667 \\
V & 0,2 & 0,2 & 0,4 & 0,207 \\
Eugenol & 2,2 & 1,5 & 2,5 & 2,067 \\
\hline
\end{tabular}


Formulasi dan uji aktivitas antibakteri Patch bukal mukoadhesif estrak cengkeh dengan kombinasi Polimer Polivinil Pirolidon dan Natrium Karboksimetil Selulosa terhadap bakteri Streptococcus mutans

\section{PEMBAHASAN}

Sistem penghantaran bukal mukoadhesif merupakan salah satu bentuk penghantaran obat yang diaplikasikan dengan cara meletakkan obat diantara gusi dengan membran mukosa pada pipi bagian dalam. Desain patch bukal teofilin melibatkan penggunaan beberapa bahan yaitu PVP dan Na-CMC yang berfungsi sebagai polimer pembentukan matriks, polisorbat 80 sebagai bahan pendispersi (dispersant). Propilen glikol sebagai plastisizer yang berfungsi untuk meningkatkan fleksibilitas dan elastisitas patch yang dibuat.

\section{Pengamatan Organoleptik}

Pengujian

organoleptik dilakukan untuk melihat warna dan transaparansi dari patch yang di buat. Dari hasil penelitian diperoleh hasil bahwa warna dari semua patch (formula I-V) memiliki warna coklat tua dan transparansi patch opaq. Warna dan opaq dari patch tersebut kemungkinan disebabkan karena adanya polisorbat 80 yang digunakan untuk mendispersikan ekstrak cengkeh di dalam patch.

\section{Tekstur Permukaan}

Pada penelitian ini menujukkan bahwa semua tekstur permukaan patch halus. Tekstur permukaan patch yang halus disebabkan karena polimer yang digunakan mengembang secara sempurna.

\section{Pengujian Keseragaman Berat}

Dari hasil yang diperoleh (dapat dilihat pada tabel 3 formula I dan II) menujukkan bahwa semakin tinggi konsentrasi $\mathrm{Na}-\mathrm{CMC}$ semakin berat patch yang dihasilkan, sedangkan pada formula III dan IV (tabel 3) menujukkan semakin tinggi konsentrasi PVP semakin berat patch yang diperoleh. Pada formula V dengan menggunakan kombinasi polimer Na-CMC dan PVP namun konsentrasi kedua polimer rendah sehingga berat yang dihasilkan tidak berbeda jauh dengan formula II dan III. Jika ditinjau dari standar deviasi maka formula IV merupakan formula terbaik karena memiliki standar deviasi yang paling kecil dari semua formula.

\section{Pengujian Keseragaman Ketebalan}

Hasil yang diperoleh pada pengujian keseragaman ketebalan menunjukkan bahwa semua formula memilki ketebalan yang berbeda. Ketebalan yang berbeda disebabkan karena perbedaan konsentrasi polimer Na-CMC dan PVP yang digunakan. Jika dilihat dari standar deviasi diperoleh bahwa patch dengan standar 
Formulasi dan uji aktivitas antibakteri Patch bukal mukoadhesif estrak cengkeh dengan kombinasi Polimer Polivinil Pirolidon dan Natrium Karboksimetil Selulosa terhadap bakteri Streptococcus mutans

deviasi yang paling kecil yaitu formula IV yang menggunakan polimer PVP dengan konsentrasi 3\%. Ketebalan patch yang diperoleh kemungkinan juga disebabkan karena dispersi polimer yang tidak merata diseluruh permukaan cetakan patch.

\section{Pengujian Folding Endurance}

Folding endurance merupakan pengukuran fleksibilitas dari patch. Fleksibilitas patch berkaitan dengan penggunaan patch pada mukosa bukal. Dari hasil yang diperoleh (tabel 5) menujukkan bahwa semua patch memiliki daya lipat lebih dari 300 kali. Fleksibiltas patch ditentukan oleh polimer dan plastisizer yang digunakan.

\section{Pengujian pH Permukaan}

Pengujian $\mathrm{pH}$ permukaan dari patch bukal menggunakan medium dapar fosfat $\mathrm{pH} 6,6$. Penggunaan dapar fosfat $\mathrm{pH}$ 6,6 mewakili $\mathrm{pH}$ dari lingkungan rongga mulut. Dari hasil yang diperoleh menunjukkan bahwa semua formula memiliki $\mathrm{pH}$ yang berada pada kisaran $\mathrm{pH}$ mukosa oral 6,2 - 7,4 yang berarti bahwa patch bukal yang dihasilkan tidak mengiritasi mukosa oral.

\section{Pengujian Aktivitas Antimikroba}

Pengujiaan aktivitas antimikroba (pada tabel 7) menggambarkan

keaktifan dari eugenol pada ekstrak cengkeh dalam sediaan patch untuk menghambat pertumbuhan Streptococcus mutans. Dari penelitian ini diperoleh hasil bahwa semua formula dapat menghambat pertumbuhan Streptococcus mutans namun formula IV memiliki zona hambat yang paling besar yaitu 1,667 $\mathrm{cm}$. Zona hambat formula IV hampir sama dengan zona hambat baku eugenol yaitu sebesar 2,067 cm, sehingga dapat dipastikan bahwa patch formula IV dapat mencegah terbentuknya karies gigi dengan cara menghambat pertumbuhan streptococcus mutans.

\section{KESIMPULAN}

Dari hasil penelitian dapat disimpulkan bahwa Ekstrak cengkeh dapat dibuat dalam bentuk patch bukal dengan sifat farmaseutik yang meliputi organoleptik dengan penampakan coklat tua dan berwarna opaq, tekstur permukaan halus dengan ketebalan patch dengan standar deviasi dari $\pm 0,009- \pm 0,058$, folding endurance lebih dari 300 kali, pH permukaan 6,66 - 6,72, serta aktivitas antimikroba patch bukal mukoadesif dari ekstrak cengkeh pada semua formula dapat menghambat pertumbuhan bakteri Streptococcus mutans untuk 
Formulasi dan uji aktivitas antibakteri Patch bukal mukoadhesif estrak cengkeh dengan kombinasi Polimer Polivinil Pirolidon dan Natrium Karboksimetil Selulosa terhadap bakteri Streptococcus mutans

mencegah terjadinya karies gigi,

namun formula yang memiliki zona

hambat paling besar adalah formula IV

dengan zona hambat sekitar 1,667 cm.

\section{DAFTAR PUSTAKA}

1. Wijayakusuma $H$. Atasi reumatik dan asam urat ala hembling. Jakarta : Puspa Swara, 2006.

2. Suryanto E. Fitokimia antioksidan. Surabaya: CV. Putra Media Nusantara, 2012. 165-166.

3. Syarif S. Skrining tumbuhan obat yang mempunyai aktivitas antibakteri penyebab karies gigi dan pembentuk plak. Jurnal Bahan Alam Indonesia. 2007: 6 (2).

4. Miller NS, Chittchang M, Johnston TP. The use of mucoadhesive polymers in buccal drug delivery, Adv. Drug Deliv. Rev. 2005; 57(1):1666-1691.

5. Roy S, Pal K, Anis, A, et al. Polymers in mucoadhesive drug delivery system; A brief note designed monomers and polymers. 2009; 12:483-495.

6. Bharkatiya M, Nema RK, Bhatnagar M. Development and characterization of transdermal patches of metoprolol tartrate. AJPCR. 2010; 3(2):130-134.

7. Yogananda, Rakesh B. An overview on mucoadhesive buccal patches. International Journal of Universal Pharmacy and Life Sciences. 2012; 2(2):348-373.

8. Balasubramanian, Narayana N, Senthil K, Vijaya K, Azhagesh. Formulation and evaluation of mucoadhesive buccal films of diclofenac sodium. Indian J. Innovations Dev. 2012;1:68-73.

9. Bindu, TVL, et al. Preparation and evaluation of ciprofloxacin loaded chitosan- gelatin composite films for wound healing activity. International Journal of Drug Delivery. 2010; 175.

10. Mufrod, Suwaldi, Wahyuono S. Patch esktrak daun sirih (Piper betle L.): evaluasi aktivitas antibakteri, profil pelepasan eugenol dan toleransi lokal. Traditional Medicine Journal. 2016;21(2):104-110. 